\title{
Investigating Learning English Strategies and English Needs of Undergraduate Students at the National University of Laos
}

\author{
Thongma Souriyavongsa ${ }^{1}$, Mohamad Jafre Zainol Abidin ${ }^{1}$, Rany Sam $^{1}$, Leong Lai Mei ${ }^{1} \&$ Ithayaraj Britto \\ Aloysius ${ }^{1}$ \\ ${ }^{1}$ School of Educational Studies, Universiti Sains Malaysia, Malaysia \\ Correspondence: Thongma Souriyavongsa, PhD student at School of Educational Studies, Universiti Sains \\ Malaysia, 11800, Penang, Malaysia. Tel: 601-6690-9027. E-mail: thongam_2008@yahoo.com
}

Received: June 16, 2013 Accepted: July 9, 2013 Online Published: September 4, 2013

doi:10.5539/elt.v6n10p57 URL: http://dx.doi.org/10.5539/elt.v6n10p57

\begin{abstract}
This paper aims to investigate learning English strategies and the requirement of English needs of the undergraduate students at the National University of Laos (NUOL). The study employed a survey design which involved in administering questionnaires of rating scales, and adapting the items from (Barakat, 2010; Chengbin, 2008; Kathleen A, 2010; Patama, 2001; Richards, 2001), to measure learning English strategies and the needs of English skills from 160 Lao undergraduate students of NUOL. The findings of this study revealed that speaking skill was the most important skills that students needed to improve in their undergraduate program. All participants reported a medium frequency use of strategy on learning English. The most frequently used strategies involved in using vocabulary books and electronic dictionaries to remember new English words. Based on the research findings, the researchers provided some recommendations for course developers to be reconsidered and redesigned the curriculum and syllabus including the instructional materials, learning behaviours and learning strategies of the English courses in all faculties in order to enhance the quality of learning and teaching activities as well as to meet the learners' needs and social demands for their prospective careers and country's development.
\end{abstract}

Keywords: undergraduate students, learning English strategies, English needs, NOUL

\section{Introduction}

After Laos established its independence as Lao People Democratic Republic (Lao PDR) in 1975, the English language has played the important role of the country development. Various international organizations were appropriately accepted by the government policy to assistant for developing the Lao country (Thongma, 2013). However, at that moment the English language was limited use, because the majority of the language officially used as Lao language used in official documents of the government and a medium of teaching and learning processes in institutions including secondary schools and higher education levels (Thongma, 2013).

The English language is one of the foreign languages that necessary and needed for the workplace to develop a high level of English skills in business communication. Bouangeune, Sakigawa, \& Hirakawa, (2008) identify that the demands for English is increasing among Lao people in the conditions of employments, especially within the government in seeking recruits officers with good command of English skills to attract more foreign capital for economic development. Several of occupations require the applicants who have a good English knowledge (Ratana, 2007; Young, 2008). It is believable that teaching English as a foreign language has become a priority for educational reforms and development strategies (Lazaro \& Medalla, 2004). Because of this, Laos is one of the EFL countries focuses on the English language learning in order to develop its possible to be equal to other countries (Phatchara, 2012).

In the past fifteen years, the need to learn English in Lao PDR has been increased because of the inflow of foreign investment from several countries such as China, Vietnam, Singapore, Australia, Malaysia, European Unions, and so on. Those foreign investors hope to use English as a tool for their communication. In 1996, Lao PDR was accepted to become a member of the Association of Southeast East Asian Nations (ASEAN) and World Trade Organization (WTO) members in 2012 and other international submit meetings such as $9^{\text {th }}$ Asia-Europe meeting (ASEM), Round Table Implementation Meeting (RTIM), and etc. has made learning English even more important for Lao people. Now, the English language is taught as a foreign language in schools, universities, and 
part time evening classes throughout Lao PDR (Ton \& Pham, 2010).

Unfortunately, English has not been started to teach for pupils at the primary school level in the public schools. According to the Lao National Curriculum, the English program was introduced at lower secondary school level (Siphong, 2008). However, Siphong specified that the English program was introduced into private primary schools, but the majority in the central areas, particularly in Vientiane Capital.

The instructional approaches of the English language as a foreign language in Lao PDR find plenty of factors affect language proficiency level of students low in terms of unsuitability and weakness of the English language curricula which adopted by some academic institutions, teachers' English proficiency level, teaching experiences, lack of facilities, shortage of materials, student low level of English literacy, inappropriate learning strategies and lack of confidence (Ahmadi \& Bajelani, 2012; Khattak, Jamshed, Ahmad, \& Baig, 2011; Loae, 2011; Rao, 2002). Based on these reasons, the majority of Lao students could not use English to communicate with other parties effectively. Many schools try to organize several of English learning activities to correspond the different interest of students (Ratana, 2007). Teachers, language schools, and experts in language education of Laos complained that the condition of English language teaching (ELT), including the quality of English generally in schools in Laos are still unsatisfied (Abbasi, Ahmad, \& Khattak, 2010). Particularly, speaking and listening skills are extremely difficult for Lao students to master the English language learning (Attapol, 2010). Moreover, Lao English learners' learning methods are depending on their English instructors' approaches. The majority of students are lack of understanding to deploy a variety of strategies to facilitate their learning. So, it can be said that Lao students do not use strategies to help them in the English language learning (Kanchanit, 2009).

The National University of Laos (NUOL) has policy to focus on producing the quality students at the tertiary level in the relevant fields. The English program is one that NUOL pays attention to serve. It is obviously seen all faculties, programs, and all undergraduate students are required to register to study English as a compulsory subject. Also, they must pass their English examination with the scale level of NUOL offered.

This paper aims to explore the level of use language learning strategies of undergraduates and their needs towards the English language at the National University of Laos (NUOL) in Vientiane Capital, Lao PDR. The findings of this research have the effects of the introduction of further strategies and needs that might increase their language learning capacity (Tyers, 2001).

1) What level of language learning strategies used by students at the National University of Laos?

2) What do English language skills need to be improved by NUOL students?

\section{Literature Review}

In order to understand about the theoretical framework of this study, this part of literature review provides a critical review and analysis of the literature relevant to the study. The researchers present the significant theories that related to the present study as followings:

\subsection{Language Learning Strategies}

Many researchers and scholars have been investigating the language learning and teaching methodology in a great number of different ways, and possible significance of alternative learning contexts or learner contributions such as motivation, learning styles and language learning strategies and so forth. In this study, the researchers aim to investigate the frequency of students' use various strategies for their learning English as a foreign language in the university.

The use of strategy for language learning is the methods enable students to improve their learning activities. Abedini, Rahimi, \& Zare-ee (2011) and Ratana (2007) identifies learning strategies are approaches that learners use to enrich and succeed their own learning, specially it is important for language learning because they are valuable tools that can foster learner autonomy in language learning and help learners in promoting their own achievements in language proficiency. Strategy plays its role as a key factor that influence the English language learning to gain achievement (Ikeda \& Takeuchi, 2006). Language learning strategy can help English instructors get a better understanding of their students' expectations and satisfaction with their language classes (Kasma, 2012). Sometimes the English teachers' teaching methods and cultural norms may affect the student' language learning strategies (Mohammad, 2011). So, all the instructors of the English language should find out various methods. Oxford, (1990) identifies that new teaching capacities mentions the identification of students' learning strategies, conducting training on learning strategies, and helping students become to be more independent of their learning and thinking.

Moreover, learning strategies can assist learners manage, direct, determine and guide their learning process $(\mathrm{Hu}$ 
\& Tian, 2012). The study found that learning strategies could help learners' weaknesses, for example in reading English text and learners also use strategies that do not require them to be analytical and critical (Normazidah, Koo, \& Hazita, 2012).

Therefore, strategies are considered as facilitators, or map to a language learning of students who are learning the English language as a foreign language. (Tamara, Elizabeth, Laura, Michelle, \& Nina, 2012) define that English learners can be indicated as personalities in an English speaking environment whose native language is not English. So, the language learning strategies can enhance the learners' motivation, requirements, enjoyments, and other techniques of students in learning the English language. These monitors assist them to influence their language learning achievements.

Researchers and scholars offer the definitions of language learning strategies. Kasma, (2012) identifies that language learning strategies are specific actions, methods, techniques, behaviours which enable to facilitate the storage, retrieval or utilization of the new language in order to relate to a unique context. Takač, (2008) specifies language learning strategy refers to the students' effort to learn that it has become widely recognized in the field of second language or foreign language learning. White, (2008) defines language learning strategies are the operations or procedures that students who select and employ to learn the target language (TL) or facilitate a language task. Macaro, (2001) points out strategy of a foreign language learning is a specific action that students use in order to make their learning methods easier, faster, more enjoyable, self-directed, effective and transferable to the new situational environment. Learning English strategies refers to a range of behaviour, techniques of learning in both outside and inside classes, activities of specific English, and step used by a foreign language learning students in order to make them receive their learning achievement (Kanchanit, 2009).

Students study English as a foreign language (EFL) may use more cognitive strategies such as using pictures, saying and writing words repeatedly, and skimming texts (Tomoko \& Osamu, 2009). Communication strategies are developed and used by the learners such as techniques of coping with difficulties in communication in an imperfectly known second language (Junhong \& Stella, 2007). However, Michae \& Harris, (1999) lists of ten strategies that used by the good language learner: 1 Planning strategy. 2) Active strategy. 3) Empathetic strategy. 4) Formal strategy. 5) Experimental strategy. 6) Semantic strategy. 7) Practice strategy. 8) Communication strategy. 9) Monitoring strategy. 10) Internalization strategy. (p. 37). Tragant, Thompson, \& Vicrori (2013) offer strategies descriptions which are categorized into six strategy types:

1) Memory strategies for vocabulary learning;

2) Cognitive strategies for text comprehension and production;

3) Compensation strategies to overcome lack of knowledge;

4) Metacognitive strategies for regulating learning processes;

5) Effective strategies for the management of feelings;

6) And social strategies involving interaction with others (P. 2)

Besides, feedback strategy was accepted to be a significant tool in learning and teaching a foreign language such as direct corrective strategy, peer feedback strategy (Kamberi, 2013).

Hence, the successful language learner uses more effective diverse strategies such as use of memory, taking advantage of practice opportunities, cognitive, metacognitive, social strategies, while a poor language learner uses a few strategies or more use compensation strategies (Dörnyei, 2001; Michae \& Harris, 1999; Neala \& Moira, 2008; Orawee \& Thanyapa, 2011). The researches were conducted by (Farzad, Mahnaz, \& Neda, 2013; Haifa, 2010; Kavasoğlu, 2009) on language learning strategies found that the majority of students preferred to use metacognitive strategies in high level up to $75.3 \%$, while the use of effective strategies up to $58.3 \%$ and cognitive strategies were the least frequent use. The studies also describe that metacognitive strategies typically enhance a strong instrumental motivation for students who are learning English program as major.

Ting, (2009) identifies that the term 'strategy' has been referred to a small range of synonyms such as techniques, skills, by which individual researchers describe their understandings in this particular area in slightly different ways in the literature involving cognitive science in general. Goh, (2002) states that strategy, in cognitive psychology, is connected to the conceptual framework of human learning and memory and refers to mental steps or operations conducted to achieve cognitive tasks such as map-reading, memorization, processing information and problem solving.

Consequently, the learning strategies are considered as key factors that influence students' language learning achievements. It is possible that the students can find out a different diversity of strategies to enhance their 
learning methods such as they might use the practices communicating in the language, use various memorization techniques, ask questions for clarification, and so forth. Neala \& Moira, (2008) identified successful learners use strategies appropriate to their own stage of learning, purpose for learning the language, and some factors that can be effective learning such as motivation, the ways how to practice the language, whereas, less successful students in language learning also use their own strategies, but do not well understand how to apply the appropriate strategies. Thus, it can be said that strategy training is important and essential in helping students utilize suitable learning strategies to improve English language learning (Sadeghi \& Attar, 2013).

\subsection{The English Language Needs}

Richards (2001), identifies that the English language needs of students in institutions influence the learning and teaching situations. An investigation of learners' needs in a foreign language learning is a key factor that a language instructor and course designer perceive learners' wishes and wants that curriculum or syllabus designer should take consideration (Mohammad, 2011). To obtain information of learners' needs in language learning, needs analysis is one of the most important methods as Brown (1995), specifies that needs analysis (NA) in language teaching may be used for a number different purposes. For example, to find out what language skills a learner needs to perform a particular role such as sales management, tour guide, or a university student. NA is an influential instrument that helps clarify and validate real needs, because it can enhance educators and practitioners to shape the curriculum development that depends the content of language courses on the communication needs, wants and interests of the learners (Akyel \& Ozek, 2010).

An exploration of what English language skills are essential thing that enable students to take part in all schools and community activities in English (Brown, 1995). In this study, the English language needs of students refer to the language skills that learners need to improve on their learning English as a foreign language at a tertiary level. For instance, the four main language skills: listening, speaking, reading, writing, and including in other skills. The researchers need to know and understand what the English language learners' requirements towards their improvement in English learning. So, the results of this study will be useful in curriculum development in the field of foreign language program. Besides, it is necessary for the lecturers and course designers have to think about and consider their students' needs and other the new trends may be foreseen (Yurtsever, 2013). Abiri (2013), conducted a study on the exploration of English needs of students and teachers. The results found that students lack of confidence to speak, they need the speaking skills for group discussion and presentation. Hashemi, (2011) points out that worldwide growth of English Language have increased the demand to obtain good communication skills in English. For this, students can use their learning needs and preferences, their beliefs and motivation, and the strategies to develop their target language learning competence (White, 2008).

The learners' needs were mainly effective in establishing the focus of the needs-based course in terms of skills (Chostelidou, 2010). The situations of learning and teaching approaches should meet the learners' actual needs in order to relate attention to curriculum development (Chamnong, 2009).

\section{Methodology}

\subsection{Research Design}

Creswell (2008) \& Kothari (2004) identify that research design is a plan and procedure including the conceptual structure within which research is conducted and span decisions from broad assumptions to detailed methods of data collection and analysis. Learning strategies are conceptual structures Akyel \& Ozek, (2010). Kothari also pointed out that research design is needed because it facilitates the smooth operation of research. The purpose of this study was to investigate English language needs and their use of learning strategies for the solutions of the Lao undergraduate students of the National University of Laos (NUOL). In the present study, the researchers applied a quantitative method, using a questionnaire to collect data and interpreting the findings in terms of English needs and their learning strategies. The details of the participants, questionnaire, data collection, and data analysis are as followings:

\subsection{Participants}

The participants of this study refer to the Lao undergraduates who were learning at all faculties at the National University of Laos, in main campus. The study was conducted with a group of students who were in the fourth year of their study programs. Those students were required to take an English course as a compulsory subject in the programs in each semester from year one to year five. The participants were 160 learners, 72 males and 88 females. The researchers used both purposive sampling and the random sampling methods to select the representatives of the population. Twenty students were selected from eight faculties at NUOL. A random sampling is an appropriate method to be used for collecting quantitative data. According to VanderStoep \& 
Johnson, (2009) identify that a random sampling is a sample in which each individual of the sampling frame has an equal opportunity of being chosen as a study participant and it also involves picking a real number of participants out of the total of possible participants in the sampling frame. Whereas, purposive sampling was used in this study in order to select 20 participants from each faculty. Kothari, (2004) specifies that this type of sample, the researchers are able to select items for the sample deliberately. It is also called judgment sampling because it a process of selecting a sample that is believed to representative of a given population. Dawson, (2002) points out that a purposive sampling method can be used in case of generalization, is not the goal.

\subsection{Research Instrument}

A questionnaire was used in investigating and gathering information about the Lao students' needs in the English language learning and their learning English strategies. The questionnaire contains three sections with 65 questions all in all. Section one was divided into two parts: A and B. Part A was designed to obtain demographic information about the samples regarding age and gender. Part B was designed to obtain information regarding general statements about their English learning skills: listening, speaking, reading, writing, translating and grammar. So, the respondents were to answer 7 questions in this section. Next, section two contained a set of questions that regarding learning English strategies. In this construct, thirty questions were used to investigate the participants' frequency of utilization of various language learning strategies. At this point, a five-point Likert scale was used. The frequency of their learning strategies to each statement was indicated by 1 (never), 2 (rarely), 3 (sometimes), 4 (often), and 5 (very often). Finally, section three included 24 statements to explore the participants' needs of English language skills improvement. A five-point Likert scale was also used in this section. The level of their needs to each statement was indicated by 1 (very low), 2 (low), 3 (moderate), 4 (high), and 5 (very high). The details of the score giving in section $2 \& 3$ can be seen on page 8 . The respondents need to tick their level of needs to skills improvement. The questionnaire used in this study was adapted from previous studies which conducted by researchers: (Barakat, 2010; Chengbin, 2008; Kathleen A, 2010; Patama, 2001; Richards, 2001). Next, two experts in the field of TESOL from the school of Educational Studies (SES), University Sciences Malaysia (USM) were asked to check content validity of the questionnaire and their feedback were used to make modifications prior to conducting a pilot study.

Before conducting a pilot study, the questionnaire was translated into the Lao language by the researcher in order make the respondents easy to understand the questions or preventing any misunderstanding. Three experts of bilingual (English-Lao) were asked to check content validity. After that the questionnaire was conducted a pilot study with 40 students in a group of Lao students at NUOL who were not the target group of the actual study. A pilot study was carried out to obtain the reliability of the research instrument. So, Cronbach's Alpha was used as a measure of internal-consistency. Cronbach's Alpha was calculated using the statistical package for the social science (SPSS) program Version 19. Obtained Cronbach's Alpha from the pilot study indicates an overall reliability coefficient of .863 which is considered ideal.

\subsection{Data Collection}

The researchers administered the questionnaires in the middle of April for the actual study. A total of these 175 of Lao undergraduate students respond to the questionnaires. The questionnaires were given to the respondents during their class hours and a half hour is given to complete the questionnaire. The return rate is $100 \%$ and selected 160 completed questionnaires were used for data entry.

\subsection{Data Analysis}

Data collected from the questionnaires were analysed using the Statistical Package of Social Sciences (SPSS) program version 19. Descriptive analysis of frequency, percentage, mean and standard deviation was conducted for all the items in the questionnaire to explore English proficiency level, language learning strategies, and needs of English skills improvement of NUOL students respectively.

\section{Findings}

To acquire a sample that would be representative of Lao students in Lao P. D. R., 160 undergraduate students who study year 4 in any programs of the National University of Laos (NUOL) are participants in this current research paper. Thus, to understand the variables in this study, descriptive statistical analyses were carried out. Table 1 through 9 displayed information regarding sex, age, and general statements which include the duration of the year study English, hours studying English in each week, English proficiency level, frequency level of difficulty of English skills, frequency of expectation to use English skills, the importance of success in the course of study, and the importance of success in the field after graduation of the participants.

The results of statistical analysis were presented in this section also to inform the frequency of practice in 
learning English strategies and the level of the English language skills needed to improve. The questionnaires were computed for means $(\times)$ and standard deviation (SD) in order to explain the learning English strategies and skills need to improve perceived by Lao students at NUOL. The learning English strategies were classified into five levels: $1=$ never, $2=$ rarely, $3=$ sometimes, $4=$ often, $5=$ very often. The English skills needed to improve were also divided into 5 levels: $1=$ very low, $2=$ low, $3=$ moderate, $4=$ high, $5=$ very high.

Reporting frequency of use in learning strategies, strategy inventory for language learning (SILL) developed by (Oxford, 1990), cited in (Ratana, 2007) provides the basic framework to understand the mean score on the students' SILL and the level of need, which has a scale range of 1-5:

The interpretation data of frequency use learning strategies

$\begin{array}{lll}\text { High } & \text { Very often use } & 4.5 \text { to } 5.0 \\ & \text { Often use } & 3.5 \text { to } 4.4 \\ \text { Medium } & \text { sometimes use } & 2.5 \text { to } 3.4 \\ \text { Low } & \text { Rarely use } & 1.5 \text { to } 2.4 \\ & \text { Never use } & 1.0 \text { to } 1.4\end{array}$

The interpretation data for the English language needs to improve

$\begin{array}{ll}\text { Very low need } & 1.0 \text { to } 1.4 \\ \text { Low need } & 1.5 \text { to } 2.4 \\ \text { Moderate need } & 2.5 \text { to } 3.4 \\ \text { High need } & 3.5 \text { to } 4.4 \\ \text { Very high need } & 4.5 \text { to } 5.0\end{array}$

Table 1. Participants sorted by their genders

\begin{tabular}{lll}
\hline Gender & Number of Frequency & Percentage (\%) \\
\hline Male & 72 & 45 \\
Female & 88 & 55 \\
Total & 160 & 100 \\
\hline
\end{tabular}

As indicated in table 1 , shows that the majority of participants are female 88 by which $55 \%$, while the male are 72 of which $45 \%$.

Table 2. Participants sorted by their ages

\begin{tabular}{lll}
\hline Group of Age & Number of Frequency & Percentage (\%) \\
\hline $17-21$ & 70 & 43.80 \\
$22-26$ & 86 & 53.80 \\
$27-31$ & 2 & 1.30 \\
32 & 1 & .60 \\
Total & 160 & 100 \\
\hline
\end{tabular}

From table 2, it shows that the number of the respondents was arranged from 17-32 years old. The most of them $88(53.80 \%)$ were aged $22-26$ while the $70(43.80 \%)$ were aged $17-21$ is medium and $1(0.60 \%)$ was aged 32 is low. 
Table 3. The participants' period of studying English

\begin{tabular}{lll}
\hline Number of years & Number of Frequency & Percentage (\%) \\
\hline Never & 10 & 6.30 \\
$1-2$ & 57 & 35.60 \\
$3-4$ & 52 & 32.50 \\
$4-6$ & 35 & 21.90 \\
7 & 6 & 3.80 \\
Total & 160 & 100 \\
\hline
\end{tabular}

As table 3 shows that the duration of participants in English studying experiences the most of them 57 (35.60\%) was $1-2$ years. Whist, $52(32 \%)$ have been studying English for $3-4$ years and $10(6.30 \%)$ of the participants have never studied English.

Table 4. Participants' hours of their study English per week

\begin{tabular}{lll}
\hline Number of hours & Number of Frequency & Percentage (\%) \\
\hline Do not study & 1 & .60 \\
$1-5$ & 44 & 27.50 \\
$6-10$ & 47 & 29.40 \\
$11-15$ & 41 & 25.60 \\
16 & 27 & 16.90 \\
Total & 160 & 100 \\
\hline
\end{tabular}

Table 4 showed that the majority of participants are 47 (29.40\%) usually study English for 6-10 hours per week. The data also indicated that $44(27.50 \%)$ spent their time in 1-5 hours a week, $41(25.60 \%)$ enjoyed studying English 11-15 hours, and $27(16.90 \%)$ take their time for studying English up to 16 hours. However, only 1 $(0.60 \%)$ do not study any English in a week.

Table 5. Participants' English proficiency level in these items below

\begin{tabular}{lllll}
\hline No & Items & Mean & Std Deviation & Level \\
\hline 1 & Listening skill & 2.76 & .73 & Moderate \\
2 & Speaking skill & 2.91 & .76 & Moderate \\
3 & Reading skill & 3.51 & .74 & Good \\
4 & Writing skill & 3.07 & .74 & Moderate \\
5 & Translating skill & 2.80 & .75 & Moderate \\
6 & Grammar skill & 2.88 & .80 & Moderate \\
Total & & 2.99 & .75 & Moderate \\
\hline
\end{tabular}

From table 5, the information was revealed that the participants' English proficiency level of language skills which was rated at the moderate level. Except for reading skill averages 3.51 is good. 
Table 6. The difficulty of language skills that encountered by the participants

\begin{tabular}{lllll}
\hline No & Items & Mean & Std Deviation & Frequency level \\
\hline 1 & Listening skill & 3.23 & .70 & Sometimes $(50 \%)$ \\
2 & Speaking skill & 3.13 & .74 & Sometimes (50\%) \\
3 & Reading skill & 3.01 & .81 & Sometimes (50\%) \\
4 & Writing skill & 3.24 & .75 & Sometimes (50\%) \\
5 & Translating skill & 3.35 & .75 & Sometimes (50\%) \\
6 & Grammar skill & 3.33 & .83 & Sometimes (50\%) \\
Total & & 3.21 & .76 & Sometimes $(50 \%)$ \\
\hline
\end{tabular}

As revealed in table 6, students had sometimes difficulties in applying English skills in which the overall picture all skills with the mean are 3.21 with the standard deviation of 0.76 .

Table 7. Participants often are expected to use the following skills in their course of study

\begin{tabular}{lllll}
\hline No & Language Skills & Mean & Std Deviation & Frequency Level \\
\hline 1 & Listening skill & 3.46 & .93 & Sometimes (50\%) \\
2 & Speaking skill & 3.65 & .89 & Often (70) \\
3 & Reading skill & 3.71 & .86 & Often (70) \\
4 & Writing skill & 3.65 & .83 & Often (70) \\
5 & Translating skill & 3.60 & .84 & Often (70) \\
6 & Grammar skill & 3.54 & .87 & Often (70) \\
Total & & 3.61 & .87 & Often (70) \\
\hline
\end{tabular}

From table 7, a statistic data showed that the participants hoped to use the English skills in their course of study at the majority is often or $70 \%$ of the mean is 3.61 and with the standard deviation of 0.87 , but one of all skills is reading skill is the most of the mean is 3.71 and with the standard deviation of 0.86 . However, just only listening skill will be used as sometimes or equal $50 \%$.

Table 8. The importance of success in the participants' course of study in the following abilities

\begin{tabular}{lllll}
\hline No & Language Skills & Mean & Std Deviation & Level \\
\hline 1 & Listening skill & 3.76 & .91 & High \\
2 & Speaking skill & 3.93 & .97 & High \\
3 & Reading skill & 3.81 & .83 & High \\
4 & Writing skill & 3.83 & .88 & High \\
5 & Translating skill & 3.85 & .92 & High \\
6 & Grammar skill & 3.73 & .93 & High \\
Total & & 3.81 & .90 & High \\
\hline
\end{tabular}

Table 8 showed that participants understood English skills are important for their course of study during their studying at NUOL. They rated all skills in high level in the mean is 3.81 with the standard deviation of 0.90 . However, the most skill is speaking skill means is 3.93 with the standard deviation of 0.97 . 
Table 9. Importance of success in participants' field study after the graduation in the following abilities

\begin{tabular}{lllll}
\hline No & Language Skills & Mean & Std Deviation & Level \\
\hline 1 & Listening skill & 3.85 & .96 & High \\
2 & Speaking skill & 4.09 & .93 & High \\
3 & Reading skill & 3.95 & .81 & High \\
4 & Writing skill & 3.95 & .86 & High \\
5 & Translating skill & 3.95 & .94 & High \\
6 & Grammar skill & 3.86 & .98 & High \\
Total & & 3.94 & .91 & High \\
\hline
\end{tabular}

From table 9, the results of data analysis indicated that the English language skills are important for the participants' field study after they graduated from NUOL. The mean is 3.94 with the standard deviation of 0.91 , it is in high level. Particularly in the speaking skill means is 4.09 with the standard deviation of 0.93 .

Table 10. Means and standard deviation of English language learning strategies

\begin{tabular}{|c|c|c|c|c|}
\hline No & Language Learning Strategies & Mean & $\begin{array}{l}\text { Std } \\
\text { Deviation }\end{array}$ & $\begin{array}{l}\text { Frequency } \\
\text { Level }\end{array}$ \\
\hline 1 & I try to talk to native speakers. & 2.86 & .93 & Sometimes \\
\hline 2 & $\begin{array}{l}\text { If I don't understand something in English, I ask the } \\
\text { other persons to slow down or say it again. }\end{array}$ & 3.45 & .91 & Sometimes \\
\hline 3 & $\begin{array}{l}\text { I ask my English teacher of fluent speakers of English } \\
\text { to correct me when I talk. }\end{array}$ & 3.53 & .99 & Often \\
\hline 4 & I practiced English with other students. & 3.20 & .90 & Sometimes \\
\hline 5 & I ask for help from my English teacher or my friends. & 3.37 & .94 & Sometimes \\
\hline 6 & $\begin{array}{l}\text { I use new English words in a sentence so that I can } \\
\text { remember them. }\end{array}$ & 3.10 & 1.02 & Sometimes \\
\hline 7 & $\begin{array}{l}\text { I use vocabulary books and /or electronic dictionaries } \\
\text { to remember new English words. }\end{array}$ & 3.65 & 1.07 & Often \\
\hline 8 & I say or write new English words several times. & 3.19 & .98 & Sometimes \\
\hline 9 & I review English lessons often. & 3.15 & .93 & Sometimes \\
\hline 10 & $\begin{array}{l}\text { I was translating into my own language while I was } \\
\text { reading English books/materials. }\end{array}$ & 3.47 & .91 & Sometimes \\
\hline 11 & $\begin{array}{l}\text { I watch movies spoken in English or TV programs } \\
\text { spoken in English, such as cartoons and news report. }\end{array}$ & 3.25 & .90 & Sometimes \\
\hline 12 & I write diaries or short articles in English. & 2.63 & 1.02 & Sometimes \\
\hline 13 & $\begin{array}{l}\text { I make summaries of information that I hear or read in } \\
\text { English. }\end{array}$ & 2.58 & .89 & Sometimes \\
\hline 14 & I like to make an outline before I start writing. & 2.63 & .90 & Sometimes \\
\hline 15 & I write e-mail in English. & 3.23 & 1.14 & Sometimes \\
\hline 16 & $\begin{array}{l}\text { I listen to the radio programs spoken in English and } \\
\text { English songs played in tapes or CDs. }\end{array}$ & 3.26 & 1.04 & Sometimes \\
\hline & $\begin{array}{l}\text { I find the meaning of an English word by dividing it } \\
\text { into parts that I understand, such as roots, prefixes, and }\end{array}$ & & & \\
\hline
\end{tabular}


$17 \quad$ suffixes.

18

30

Total
2.70

.96

Sometimes

I try not to translate word- for word into my own language.

3.01

1.03

Sometimes

When I can't think of a word during a conversation in English, I use gestures.

3.37

.95

Sometimes

I make up new words if I don't know the right ones in English.

3.54

.95

Often

3.06

1.02

Sometimes

If I can't think of an English word, I use a word or phrase that means the same thing.

3.34

1.00

Sometimes

I notice my English mistakes and use that information to help me do better.

3.33

1.02

Sometimes

I try to find out how to be a better learner of English.

3.59

1.02

Often

I plan my schedule so I will have enough time to study English.

3.08

.98

Sometimes

I think of my progress in learning English.

$3.53 \quad .91$

Often

$3.21 \quad .95$

Sometimes

$3.55 \quad .93$

Often

3.50

.99

Sometimes

$3.34 \quad 1.11$

Sometimes

$3.23 \quad 0.97$

Sometimes

According to the research question 1, what is the level of use of language learning strategies by the National University of Lao students? From table 10, the results showed that the items of number 7, 24, 28, 24, and 3 the students use often. It means that these activities were used up to $70 \%$. The mean of five items is 3.57 with the standard deviation of 0.99 . Moreover, the data also indicated that besides the items $7,24,28,24$, and 3 the participants use these items for their English learning activities as sometimes. However, the activity that the most of students use is the question I use vocabulary books and lor electronic dictionaries to remember new English words, the mean is 3.65 with the standard deviation of 1.07. The activity of the question I make summaries of information that I hear or read in English. The participants rarely used it which the mean is 2.58 with the standard deviation of 0.89 . In general, activity number 1 to 30 total average was used with frequency level is sometimes (50\%) with the means is 3.23 with its standard deviation of 0.97 .

Table 11. Means and standard deviation of the English language skills are needed to improve

\begin{tabular}{lllll}
\hline No & English language Skills needed to be improved & Mean & Std Deviation & Level \\
\hline 1 & Listening skills. & 3.84 & 1.01 & High \\
2 & Speaking skills. & 4.10 & .92 & High \\
3 & Reading skills. & 3.82 & .85 & High \\
4 & Writing skills. & 3.86 & .91 & High \\
5 & Grammatical structures. & 3.83 & .97 & High \\
6 & Translational techniques. & 3.97 & 1.06 & High \\
7 & Conversational English ability. & 4.18 & 1.01 & High \\
8 & Give a presentation in English. & 3.63 & .90 & High \\
\hline
\end{tabular}




\begin{tabular}{|c|c|c|c|c|}
\hline 9 & English language teaching techniques. & 3.69 & .90 & High \\
\hline 10 & $\begin{array}{l}\text { English for sciences (e.g., English for computer, } \\
\text { chemistry, mathematics, and etc.). }\end{array}$ & 3.43 & .90 & Moderate \\
\hline 11 & $\begin{array}{l}\text { Communicating effectively with peers in small group } \\
\text { discussion, collaborative projects, or out-of-class study } \\
\text { groups. }\end{array}$ & & & \\
\hline & & 3.55 & .88 & High \\
\hline 12 & $\begin{array}{l}\text { English for Specific Purposes (e.g., tourism, business, } \\
\text { technology, and etc.). }\end{array}$ & 3.77 & .95 & High \\
\hline 13 & Writing essay. & 3.63 & .98 & High \\
\hline 14 & Knowledge of vocabulary. & 3.81 & .86 & High \\
\hline 15 & General reading comprehension. & 3.78 & .88 & High \\
\hline 16 & Pronunciation. & 3.88 & 1.01 & High \\
\hline 17 & Test of English as a Foreign Language (TOEFL). & 3.76 & .98 & High \\
\hline 18 & $\begin{array}{l}\text { International English Language } \\
\text { (IELTS). }\end{array}$ & 3.73 & .99 & High \\
\hline 19 & Technical terms in your area of specialization. & 3.81 & .92 & High \\
\hline 20 & English for public speaking skills. & 3.78 & .91 & High \\
\hline 21 & $\begin{array}{l}\text { English for general staff (a long distance phone } \\
\text { operation, interview, and etc.). }\end{array}$ & 3.84 & .91 & High \\
\hline 22 & Learn to use PC software to study English. & 3.65 & 1.04 & High \\
\hline 23 & Write papers and reports in English. & 3.71 & 1.03 & High \\
\hline 24 & English for Advertisements. & 3.69 & .96 & High \\
\hline Total & & 3.78 & 0.94 & High \\
\hline
\end{tabular}

From table 11, based on the research question number 2, "What are the English language skills do NUOL students need to improve more?" The statistical data analysis pointed out that there are high needs among the English skills of 24 items. In overall, the means are 3.78 with its standard deviation of 0.94; except for the item number 10 "English for sciences (e.g., English for computer, chemistry, mathematics, and etc.)" the level of need is moderate. The mean is 3.43 with the standard deviation of 0.90 .

However, the data indicated that the highest item score that the participants need is to improve conversational English ability which has mean is 4.18 with the standard deviation of 1.01 . The following one is the item of speaking skills that obtains the score up to 4.10 with the standard deviation of 0.92 .

\section{Discussion}

The aim of this research paper was to explore 160 undergraduate students from eight faculties throughout the National University of Laos (NUOL) in learning English as a foreign language (EFL). The specific goal in this study was to investigate students' use of strategies for their language learning and their English needs for other skills which they would like to learn. Besides, the study also determined the students' English language proficiency level throughout the four main language skills that consisting of listening, speaking, reading and writing as well as translational skills, grammatical skills, the importance of the English language that would empower to the students' course study in both during their studying at the university and after their graduation.

Based on the general statements part of the questionnaires, the results revealed that the participants' English proficiency level generally is in the moderate, reading skill is the highest one means equal 3.51 and with the SD of .74, except for the listening skill is low level means 2.76 and with the SD of .73. The students stated that they found difficulties in their using English language skills: listening, speaking, reading, writing, translation, and grammar is in sometimes. A total means is in 3.21 and with the SD of .76. All those skills, students often expect to use English for their course study during their course at the university, a total means is 3.61 and with the SD of .87 . Thus, they thought that these skills were often important factors for both their present course study 
and after their graduation are in high levels needs. A total mean is 3.81 and with the SD of .90 for during their studying at university, and for their after graduation means is 3.94 and with the SD .91.

It is now possible to discuss about the two main questions that posed earlier. The first question was what level of language learning strategies used by students at the National University of Laos? The results of this study found that the students often use the strategies for their English language learning activities consisting of six strategies: 1) I use vocabulary books and /or electronic dictionaries to remember new English words. A total means is 3.65 and with the SD 1.07. 2) I try to find out how to be a better learner of English. A total means is 3.59 and with the SD of 1.02. 3) I have many creative ways to solve a problem. A total means is 3.55 and with the SD of .93. 4) I think of my progress in learning English. A total means is 3.55 and with the SD of .91. 5) I make up new words if I do not know the right ones in English. A total means is 3.54 and with the SD of .95. 6) I ask my English teacher of fluent speakers of English to correct me when I talk. A total means is 3.53 and with the SD of .99. Besides, the students sometime used various different strategies for their studying English activities. For the details, the researchers requested the reads look at the table 10 above. However, all the 30 questions in the part of the language learning strategy mean is in 3.23 and with the SD of .97 was considered the frequency level of use various strategies for their language learning is sometime.

The second question was what does English language skills need to be improved by NUOL students? The statistical data analysis indicated that the NUOL students needed to improve their English skills is conversational English abilities and speaking skills are the highest ones mean is 4.18 and with the SD of 1.01 for conversational English ability, for the speaking skill mean is 4.10 and with the SD of .92. However, all the questions in the part of questionnaire of English language needs consisting of 24 items are needed in the high level means is 3.78 and with the SD of .94.

According to the results mentioned above which obtained similarity with the research conducted by (Ratana, 2007) entitled "An Investigation of Thai Students' English Language Problems and Their Learning Strategies in the International Program at Mahidol University" found that the majority of Thai students had difficulty with speaking skills, they needed to improve. The frequency of strategy use among students was medium or sometimes.

\section{Conclusion}

This research paper was conducted in order to find out English language learning strategies and the English language needs of the Lao undergraduate students at the National University of Laos (NUOL) with two areas of research questions. 1) What level of language learning strategies used by students at the National University of Laos? 2) What do English language skills need to be improved by NUOL students?

The instrument was applied for this study was a questionnaire which adapted from the previous studied which conducted by (Barakat, 2010; Chengbin, 2008; Kathleen A, 2010; Patama, 2001; Richards, 2001) as mentioned in the part of research methodology. The questionnaire contains three sections with 65 questions. Section one consists of two parts: Part A was designed to obtain demographic information about the samples regarding age and gender. Part B was designed to obtain information regarding general statements about their English learning skills. Section two contains a set of questions that regarding learning English strategies. Section three included 24 statements to explore the participants' needs of English language skills improvement. At this point, a five-point Likert scale was used. The frequency of their learning strategies to each statement was indicated by 1 (never), 2 (rarely), 3 (sometimes), 4 (often), and 5 (very) and the level of their needs to each statement was indicated by 1 (very low), 2 (low), 3 (moderate), 4 (high), and 5 (very high).

A total of 160 participants in the present study are 72 males (45\%) and 88 females (55\%). Most participants aged 22-26 up to 86 (53.80\%). The majority of participants have studied English between 1-2 years up to 57 (35.60\%). The majority of participants studied English 6-10 hours per week up to 47 (290.40\%).

The results revealed that the majority of students are low in speaking skill and conversational English abilities. In general picture, however, the students' English proficiency level is in the moderate. Besides this, the frequency level of the use the activities for their learning English is the use vocabulary books and /or electronic dictionaries to remember new English words is the highest one of all those activities which the mean is 3.6 and with the standard deviation (SD) of 1.07, but the total average of all activities that the students use for their learning English strategies are in the sometimes of the frequency level means 3.23 with the SD of 0.97 . For the part of English needs to be improved, the students need to improve the speaking skill in a high level means 4.10 with the S.D of 0.92 .

The results of this research paper could recommend an overview, reconsider and redesign of the curriculum and 
syllabus, including the instructional materials, learning behaviours and learning strategies of the English courses in all faculties to fit with the learners' needs and society requirements to enhance an effective learning and teaching of the quality.

Therefore, based on the present study collected data from only a questionnaire to specify the level of frequency of use strategies for the language learning of undergraduates and their needs towards the English language, it is suggested that further studies to combine several methods of measurement of English language learning and solutions for example, interviews, class observations, case study, and etc. the secondly, we recommended teachers, administrators, curriculum developers and throughout the all parts of stakeholders study the students' needs and their learning strategies in the deeper ways in order to correspond to the society and learners' requirements.

\section{Acknowledgements}

The researchers would like to take this opportunity to extend our gratitude to USM Fellowship that support the financial on conducting the research during our $\mathrm{PhD}$ candidates (students) for three years. We also give thanks to Ms. Sengsavanh Souriyavongsa and Mr. OnSee Khamphouvong help us in collecting data. Moreover, the researchers have great thanks to all respondents the questionnaire from all Faculties of the National Univesity of Laos, Lao P.D.R.

\section{References}

Abbasi, M. G., Ahmad, A., \& Khattak, Z. I. (2010). Negative influence of large scale assessment on language learning strategies of the Secondary School Certificate (SSC) students. Procedia-Social and Behavioural Sciences, 2(2), 4938-4942.

Abedini, A., Rahimi, A., \& Zare-ee, A. (2011). Relationship between Iranian EFL Learners' Beliefs about Language Learning, their Language Learning Strategy Use and their Language Proficiency. Procedia-Social and Behavioural Sciences, 28, 1029-1033. http://dx.doi.org/10.1016/j.sbspro.2011.11.188

Abiri, F. (2013). Exploration of English Needs According to Teachers and Learners in the Psychology Major in Iranian Universities. Procedia-Social and Behavioural Sciences, 70, 821-826. http://dx.doi.org/10.1016/j.sbspro.2013.01.127

Ahmadi, A., \& Bajelani, M. R. (2012). Barriers to English for Specific Purposes Learning among Iranian University Students. Procedia-Social and Behavioural Sciences, 47, 792-796. http://dx.doi.org/10.1016/j.sbspro.2012.06.736

Akyel, A. S., \& Ozek, Y. (2010). A language needs analysis research at an English medium university in Turkey. Procedia-Social and Behavioural Sciences, 2(2), 969-975.

Attapol, K. (2010). Teaching English speaking and English speaking tests in the Thai Context: A reflection from Thai perspective. English Language Teaching, 3(1), 184-190.

Barakat, H. M. (2010). Motivation and Attitude of Saudi University's Learners of English for Specific Purposes. (Doctor of Philosophy), University of Kansas.

Bouangeune, S., Sakigawa, M., \& Hirakawa, Y. (2008). Determinants and issues in student achievement in English at the Lao Secondary Education Level. The Asian EFL Journal, 10(1), 48-64.

Brown, J. D. (1995). The Elements of Language Curriculum: A Systematic Approach to Program Development. Heinle \& Heinle.

Chamnong, K. (2009). A framework for investigating learner needs: Needs analysis extended to curriculum development. Electronic journal of foreign language teaching, 6(2), 209-220.

Chengbin, Y. (2008). Language Learning Strategies in Relation to Attitudes, Motivations, and Learner Beliefs: Investigating Learner Variables in the Context of English as a Foreign Language in China. (Doctor of Philosophy), University of Maryland, College Park.

Chostelidou, D. (2010). A needs analysis approach to ESP syllabus design in Greek tertiary education: A descriptive account of students' needs. Procedia-Social and Behavioural Sciences, 2(2), 4507-4512. http://dx.doi.org/10.1016/j.sbspro.2010.03.721

Dawson, C. (2002). Practical Research Methods: A User-friendly Guide to Mastering Research Techniques and Projects. How To Books.

Dörnyei, Z. (2001). Motivational Strategies in the Language Classroom. Cambridge University Press. 
Farzad, S., Mahnaz, S., \& Neda, S. (2013). The relationship between language learning strategy use, language proficiency level and learner gender. Social and Behavioral Sciences, 70, 634-643.

Goh, C. C. M. (2002). Exploring listening comprehension tactics and their interaction patterns. C. C. M. Goh, 30, 185-206.

Haifa, A. B. (2010). Language learning strategies employed by English majors at Qatar University. Questions and Queries Asiatic, 4(2), 92-120.

Hashemi, M. (2011). Language Stress and Anxiety among the English Language Learners. Procedia-Social and Behavioural Sciences, 30, 1811-1816. http://dx.doi.org/10.1016/j.sbspro.2011.10.349

Hu, B., \& Tian, L. (2012). Do teachers and students share similar beliefs about teaching and learning strategies? System, 40(2), 237-254. http://dx.doi.org/10.1016/j.system.2012.04.001

Ikeda, M., \& Takeuchi, O. (2006). Clarifying the differences in learning EFL reading strategies: An analysis of portfolios. System, 34(3), 384-398. http://dx.doi.org /10.1016/j.system .2006.04.007

Junhong, X., \& Stella, H. (2007). Language learning strategies in distance English learning: A study of learners at Shantou Radio and Television University, China. The Journal of ASIA TEFL, 4(2), 141-164.

Kamberi, L. (2013). The Significance of Teacher Feedback in EFL Writing for Tertiary Level Foreign Language $\begin{array}{lllr}\text { Learners. Procedia-Social and Behavioural Sciences, } & \text { 16, }\end{array}$ http://dx.doi.org/10.1016/j.sbspro.2013.01.241

Kanchanit, K. (2009). The survey of English learning strategies of English major students in the Faculty of Liberal Arts Rangsity University. (Bachelor of Arts (English)), Rangsit.

Kasma, S. (2012). English language learning beliefs, learning strategies and achievement of Masters Students in Thailand TESOL in Context.

Kathleen, A. B. (2010). An Iterative Needs Assessment/Evaluation Model for a Japanese University English-Language Program. (Doctor of Education), he Temple University graduates Board.

Kavasoğlu, M. (2009). Learning strategy use of pre-service teachers of English language at Mersin University. Procedia-Social and Behavioural Sciences, 1(1), 993-997. http://dx.doi.org/10.1016/j.sbspro.2009.01.177

Khattak, Z. I., Jamshed, T., Ahmad, A., \& Baig, M. N. (2011). An Investigation into the Causes of English Language Learning Anxiety in Students at AWKUM. Procedia-Social and Behavioural Sciences, 15, 1600-1604. http://dx.doi.org/10.1016/j.sbspro.2011.03.337

Kothari, C. R. (2004). Research Methodology: Methods and Techniques. New Age International (P) Ltd.

Lazaro, D. C., \& Medalla, E. M. (2004). English as the Language of Trade, Finance and Technology in APEC: An East Asia Perspective. Philippine Journal of Development, 31(2), 278-300.

Loae, F. A. J. (2011). Problems encountered by Arab EFL learners. Language in India, 11, 19-27.

Macaro, E. (2001). Learning Strategies in Foreign and Second Language Classroom. Continuum International Publishing Group, Limited.

Michae, G., \& Harris, V. (1999). Modern Languages and Learning Strategies: In Theory and Practice. Routledge Falmer.

Mohammad, Z. (2011). An Investigation of Curriculum Elements for the Enhancement of the Teaching-learning Process. Higher Education Studies, 1(1), 67-78.

Neala, A. R., \& Moira, K. B. (2008). English as a foreign language learning strategies used by Croation learners. ANNALEL. Ser. hist. Social, 1(18), 89-96.

Normazidah, C. M., Koo, Y. L., \& Hazita, A. (2012). Exploring English language learning and teaching in Malaysia. GEMA Online TM Journal of Language Studies, 12(1), 35-55.

Orawee, P., \& Thanyapa, C. (2011). Language learning strategies used by first year students at Thaksin University, Songkhla Campus Thailand. Paper presented at the 3rd International Conference on Humanities and Social Sciences, Faculty of Liberal Arts, Prince of Songkla Univesity.

Oxford, R. L. (1990). Language learning strategies: What every teacher should know. New York: Newbury House Publisher.

Patama, K. (2001). An Assessment of the English-Language Needs of Second-Year Thai Undergraduate Engineering students in Thai Public University in Thailand in Relation to the Second-Year EAP Program in 
Engineering. (Doctor of Education in Curriculum and Instruction), West Virginia University, Morgantown, West Virginia.

Phatchara, P. (2012). English Learning Styles of High and Low Performance Students of the Faculty of Education, Khon Kaen University. Procedia-Social and Behavioural Sciences, 46, 3390-3394. http://dx.doi.org/10.1016/j.sbspro.2012.06.072

Rao, Z. (2002). Chinese students' perceptions of communicative and non-communicative activities in EFL classroom. SYSTEM, 30(1), 85-105.

Ratana, P. (2007). An investigation of Thai students' English language problems and their learning strategies in the international program at Mahidol University. (Master of Arts), King Mongkut's Institute of Technology North Bangkok.

Richards, J. C. (2001). Curriculum Development in Language Teaching. Cambridge University Press.

Sadeghi, K., \& Attar, M. T. (2013). The Relationship between Learning Strategy use and Starting Age of $\begin{array}{llll}\text { Learning EFL. Procedia-Social and Behavioural Sciences, } & \text { 70, 387-396. }\end{array}$ http://dx.doi.org/10.1016/j.sbspro.2013.01.076

Siphong, S. (2008). Developing students teachers' English learning strategies. In S. Gunnar (Ed.), Exploring Teacher Education in Laos-aims, obstacles and possibilities. Stocckholm: Stockholm University Press.

Takač, V. P. (2008). Vocabulary learning strategies and foreign language learning acquisition. Multilingual Matters Limited.

Tamara, H., Elizabeth, H., Laura, W., Michelle, M., \& Nina, C. (2012). Predictors and outcomes of early versus late English language proficiency among English language learners. Early Childhood Research Quarterly, $27,1-20$.

Thongma, S. (2013). Factors Causes Students Low English Language Learning: A Case Study in the National University of Laos. International Journal of English Language Education, 1(1), 179-192.

Ting, L. (2009). Language learning strategies - the theoretical framework and some suggestions for learner training practice. English Language Teaching, 2(4), 199-206.

Tomoko, Y., \& Osamu, T. (2009). Language learning strategies used by lower secondary school learners in a Japanese EFL context. International Journal of Applied Linguistic, 19(2).

Ton, N. N. H., \& Pham, H. (2010). Vietnamese teachers' and students' perceptions of global English. Language Education in Asia, 1, 48-61.

Tyers, C. J. (2001). An investigation into language learning strategies used by a group of Japanese learners of English (pp. 289-301).

Vander Stoep, S. W., \& Johnson, D. D. (2009). Research Methods for Everyday Life: Blending Qualitative and Quantitative Approaches. Wiley.

White, C. (2008). Language learning strategies in independent language learning: An overview. In H. Stella, \& L. Tim (Eds.), Language learning strategies in independent settings. Cromwell Press Ltd.

Young, R. F. (2008). English and Identity in Asia. ASIATIC, 2, 1-13.

Yurtsever, G. (2013). English Language Instructors' Beliefs on Professional Development Models and Preferences to Improve Their Teaching Skills. Procedia-Social and Behavioural Sciences, 70, 666-674. http://dx.doi.org/10.1016/j.sbspro.2013.01.107

\section{Copyrights}

Copyright for this article is retained by the author(s), with first publication rights granted to the journal.

This is an open-access article distributed under the terms and conditions of the Creative Commons Attribution license (http://creativecommons.org/licenses/by/3.0/). 